\title{
Yoghurt Fortified Formulation of Lakum Fruit (Cayratia trifolia (L.) Domin) Extract as an Antioxidant
}

\author{
Weni Puspita1,2, Nurkhasanah ${ }^{1 *}$, Ika Dyah Kumalasari1 \\ ${ }^{1}$ Ahmad Dahlan University, Yogyakarta; ${ }^{2}$ Akademi Farmasi Yarsi, Pontianak
}

\begin{abstract}
Lakum (Cayratia trifolia (L.) Domin) contains a lot of anthocyanin. Anthocyanin in Lakum fruit has a high stability if stored at low temperatures, acidic conditions, and without light. The acidic product such as yogurt can provide an optimum condition for anthocyanin stability and antioxidant activity. The purpose of this study was to optimize yogurt formulation fortified by lakum fruit extract as an antioxidant according to the requirements of the Indonesian National Standard (SNI). Lakum fruit extract was formulated in yogurt with various concentrations at $0 \%, 5 \%, 7.5 \%$ and $10 \%$. Evaluations were carried out including tests of physical, chemical and microbiological properties and anthocyanin test and antioxidant of yogurt. The results showed that the yogurt formula fortified lakum fruit extract at $7.5 \%$ concentration resulted highest anthocyanin stability and antioxidant activity that fulfilled SNI requirements and the preferred level of respondents' preference with anthocyanin levels of $53.35 \pm 1.04 \mathrm{mg} / \mathrm{L}$, antioxidant activity $69.15 \pm 0.24 \%$, t90 7.97 days, total of lactic acid bacteria (LAB) $48.2 \times 10^{7}$ colony/gram, fat $3.72 \pm 0.03 \%$, $\mathrm{pH} 3.87 \pm 0.03$, total acid $0.83 \pm 0.06 \%$, viscosity $639.07 \pm 2.06 \mathrm{cP}$, protein of $4.90 \pm 0.11 \%$, hedonic test, 6.88 (like), and organoleptic purple (5), the distinctive aroma of lakum fruit (4.95), sour taste (4.85), fine texture (4.9) and slightly liquid viscosity (4.85).
\end{abstract}

Key words: Formulation; lakum, cayratia trifolia (L.) Domin; antioxidant; yogurt

\section{INTRODUCTION}

Lakum contains a considerable amount of anthocyanin pigments, it also contains flavonoid, saponin and alkaloid compounds which have antioxidant activity value IC 50 about $67.383 \mathrm{ppm}$ (Yeo, and friends. 2012). Panarigas and Idiawati (2015) used lakum fruit anthocyanin pigment extract with concentration of $5 \%, 7.5 \%$, and $10 \%$ applied as natural coloring for cold beverages and agar-agar jelly. This information shows other use of lakum fruit aside from natural coloring is to give added value to the food product, i.e. as antioxidant.

Anthocyanin in lakum fruit extract has enough stability if kept in low temperature, acidic condition, and without light (Neliyanti and Idiawati, 2014). On this research, lakum fruit extract is formulated in yoghurt, which is a beverage made of milk fermented by lactic acid bacteria such as Streptococcus thermophilus and Lactobacillus bulgaricus, where this bacteria could transform lactose into lactic acid. The presence of lactic acid causes low acidity in yoghurt. Thus, this research is expected to improve the anthocyanin stability and antioxidant activity through formulation in lakum fruit extract fortified yoghurt products with low acidity. Lakum fruit extract

*Corresponding author : Nurkhasanah Email : nurkhasanah@pharm.uad.ac.id fortified yoghurt is formulated with concentration of $0 \%, 5 \%, 7.5 \%$ and $10 \%$ to find out which formula has the best stability of anthocyanin and antioxidant. Based on the background above, this research needs to be done conducted find out the formula on lakum fruit fortified yoghurt making method so it has better anthocyanin stability and antioxidant activity.

\section{METHODOLOGY}

Tools and Ingredients

Tools used on this research are UV-Visible spectrophotometry (Shimadzu ${ }^{\circledR}$ ) type 1700, autoclave (Hirayama ${ }^{\circledR}$ ), oven $\quad\left(\right.$ Memmert $^{\circledR}$ ), laminar air flow (Mascotte ${ }^{\circledR}$ ), and incubator (Memmert ${ }^{\circledR}$ ). The ingredients on this research are lakum fruits, full cream milk, pure culture of Streptococcus thermophilus and Lactobacillus bulgaricus, as well as honey. The yoghurt making formula (Table I).

\section{Yoghurt}

\section{Making Method}

Yoghurt making includes mixing bacteria starter $S$. Thermophilus and L. Bulgaricus (1:1) each about $2.5 \mathrm{ml}$ and stirred slowly. Pasteurizing 100 $\mathrm{ml}$ full cream milk with temperature of $80^{\circ} \mathrm{C}$ about 15 minutes, cooling the milk to $45^{\circ} \mathrm{C}$, and then adding bacteria culture about $5 \mathrm{ml}$, followed with 
Table I. Yoghurt Making Formula

\begin{tabular}{lcccc}
\hline \multicolumn{1}{c}{ Materials } & \multicolumn{3}{c}{ Composition } \\
\cline { 2 - 5 } & FI & FII & FIII & FIV \\
\hline Full cream milk $(13 \%)$ & $100 \mathrm{ml}$ & $100 \mathrm{ml}$ & $100 \mathrm{ml}$ & $100 \mathrm{ml}$ \\
Starter culture $(\% \mathrm{~b} / \mathrm{v})$ & 5 & 5 & 5 & 5 \\
Lakum fruit extract $(\% \mathrm{~b} / \mathrm{v})$ & 0 & 5 & 7.5 & 10 \\
Honey $(\% \mathrm{~b} / \mathrm{v})$ & 8 & 8 & 8 & 8 \\
\hline
\end{tabular}

Ref: Starter culture uses $S$. Thermophilus and L. Bulgaricus $(1: 1 \mathrm{~b} / \mathrm{v})$

\section{Research diagram}

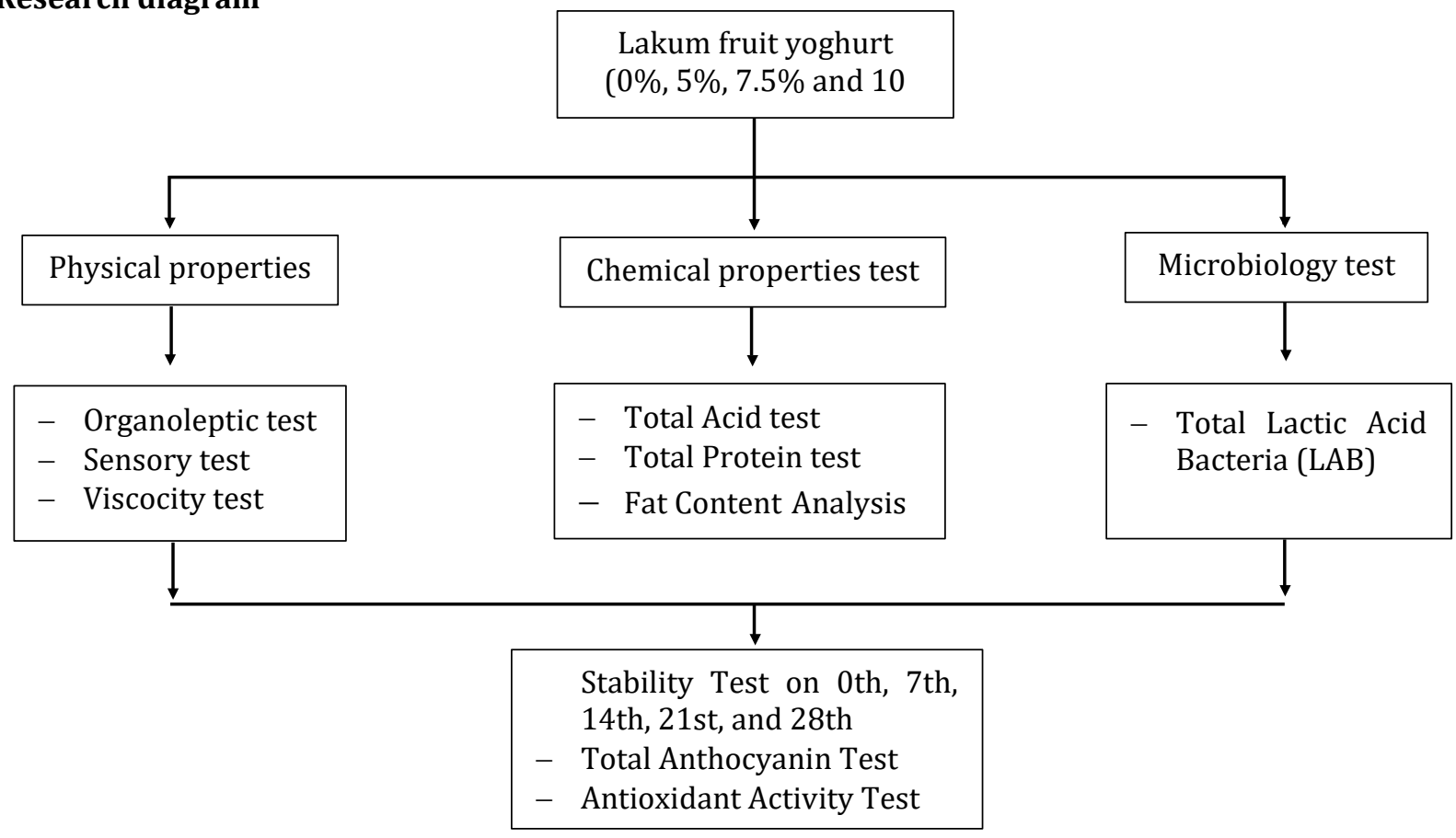

fermentation incubation in the incubator (temperature $40^{\circ} \mathrm{C}$ ) for 16 hours. Then Lakum fruit extract (Cayratia trifolia (L.) Domin) and honey is added.

\section{Yoghurt quality testing}

Yoghurt quality testing is performed by analyzing physical-chemical and microbiological characters such as organoleptic, sensory, viscosity, $\mathrm{pH}$, content of lactic acid, total protein, fat content, and lactic acid bacteria total, as well as stability testing by keeping it on $4^{\circ} \mathrm{C}$ then anthocyanin total testing using UV-Vis Spectrophotometry and activity of antioxidant using dpph method on the 0th, 7th, 14th, 21st and 28th day.

\section{RESULTS AND DISCUSSION}

Lakum fruit extract on this research is obtained by extracting using water solvent through heating for 120 minutes on $70^{\circ} \mathrm{C}$. This temperature is chosen based on research result by Neliyanti and
Idiawati (2014) which shows that the optimal anthocyanin pigment extraction from lakum fruit is on temperature of $70^{\circ} \mathrm{C}$. Further, lakum fruit extract is formulated in the form of yoghurt using lactic acid bacteria Streptococcus thermophilus and Lactobacillus bulgaricus, where these bacteria can turn lactose into lactic acid. The addition of lakum fruit extract to yoghurt aims to use lakum fruit extract as natural coloring and adds functional benefit of yoghurt as an antioxidant product due to the anthocyanin compound content. (Yeo, and friends. 2012).

The result of stability of anthocyanin content on lakum fruit extract and lakum fruit extract fortified yoghurt (Table II) average total value of anthocyanin on lakum fruit extract fortified yoghurt on day 28 is higher than lakum fruit extract which is around $22.21 \pm 2.78 \mathrm{mg} / \mathrm{L}-42.94 \pm 2.36$ $\mathrm{mg} / \mathrm{L}$, while the average of anthocyanin content on lakum fruit extract on day 28 is around $21.54 \pm 2.32 \mathrm{mg} / \mathrm{L}-36.99 \pm 0.93 \mathrm{mg} / \mathrm{L}$. Moreover, based on expiration date determination 


\section{Nurkhasanah}

Table II. Stability of Anthocyanin Content on Lakum Fruit Extract and Lakum Fruit Extract Fortified Yoghurt

\begin{tabular}{|c|c|c|c|c|c|c|}
\hline \multicolumn{7}{|c|}{ Anthocyanin Content (mg/L) } \\
\hline Sample & Day 0 & Day 7 & Day 14 & Day 21 & Day 28 & $t_{90}$ (day) \\
\hline Lakum 5\% & $48.57 \pm 1.46^{\mathrm{aD}}$ & $43.78 \pm 0.84^{\mathrm{aD}}$ & $38.41 \pm 3.27 \mathrm{aC}$ & $27.50 \pm 1.04^{\mathrm{aB}}$ & $21.54 \pm 2.32^{\mathrm{aA}}$ & 3.63 \\
\hline Lakum $7.5 \%$ & $61.73 \pm 1.13^{\mathrm{bD}}$ & $56.00 \pm 1.60^{\mathrm{bD}}$ & $46.90 \pm 1.62^{\mathrm{bC}}$ & $36.93 \pm 0.88^{\mathrm{bB}}$ & $28.92 \pm 0.63^{\mathrm{bA}}$ & 3.89 \\
\hline Lakum 10\% & $71.17 \pm 0.43^{\mathrm{cD}}$ & $67.32 \pm 0.64^{\mathrm{cD}}$ & $60.73 \pm 1.36^{c C}$ & $48.57 \pm 1.46^{\mathrm{cB}}$ & $36.99 \pm 0.93^{\mathrm{cA}}$ & 4.51 \\
\hline Plain & 0 & 0 & 0 & 0 & 0 & 0 \\
\hline Yoghurt 5\% & $38.99 \pm 2.79 \mathrm{aC}$ & $36.37 \pm 2.92^{\mathrm{aC}}$ & $35.40 \pm 2.11^{\mathrm{aC}}$ & $23.29 \pm 1.11^{\mathrm{aB}}$ & $22.21 \pm 2.78^{\mathrm{aA}}$ & 5.24 \\
\hline Yoghurt 7.5\% & $53.35 \pm 1.04 \mathrm{bc}$ & $51.32 \pm 2.14 \mathrm{bC}$ & $50.18 \pm 1.75^{\mathrm{bC}}$ & $40.10 \pm 1.06^{\mathrm{bB}}$ & $36.82 \pm 1.64^{\mathrm{bA}}$ & 7.95 \\
\hline Yoghurt 10\% & $67.02 \pm 3.95^{\mathrm{cC}}$ & $65.48 \pm 2.87^{\mathrm{cC}}$ & $62.00 \pm 1.72^{\mathrm{cC}}$ & $45.67 \pm 1.78^{\mathrm{cB}}$ & $42.94 \pm 2.36^{\mathrm{cA}}$ & 6.63 \\
\hline
\end{tabular}

Ref: ${ }^{a-c}$ on the same column with different lowercase shows a significant difference in lakum fruit extract concentration level $(p<0,05)$; ${ }^{A-D}$ on the same row with different capital letter shows significant difference with storage time $(\mathrm{p}<0,05)$

Table III. Stability of Antioxidant Activity on Lakum Fruit Extract and Lakum Fruit Extract Fortified Yoghurt

\begin{tabular}{|c|c|c|c|c|c|}
\hline \multicolumn{6}{|c|}{$\%$ of Inhibition } \\
\hline Formula & Day 0 & Day 7 & Day 14 & Day 21 & Day 28 \\
\hline Lakum 5\% & $50.91 \pm 0.52^{\mathrm{aD}}$ & $43.20 \pm 1.29 \mathrm{aD}$ & $37.48 \pm 0.38 \mathrm{aC}$ & $30.14 \pm 0.07 \mathrm{aB}$ & $25.54 \pm 1.01 \mathrm{aA}$ \\
\hline Lakum $7.5 \%$ & $59.08 \pm 1.20^{\mathrm{bD}}$ & $57.26 \pm 1.01^{b D}$ & $49.79 \pm 0.47 \mathrm{bc}$ & $39.47 \pm 0.28^{\mathrm{bB}}$ & $30.14 \pm 0.07^{\mathrm{bA}}$ \\
\hline Lakum 10\% & $64.64 \pm 0.68^{\mathrm{cD}}$ & $61.11 \pm 0.47 \mathrm{cD}$ & $52.53 \pm 1.06^{\mathrm{cC}}$ & $40.88 \pm 1.80^{\mathrm{cB}}$ & $32.88 \pm 0.64^{\mathrm{cA}}$ \\
\hline Plain & $45.48 \pm 1.88 \mathrm{aC}$ & $39.97 \pm 0.62^{\mathrm{aC}}$ & $35.95 \pm 0.69 \mathrm{aC}$ & $27.36 \pm 0.89 \mathrm{aB}$ & $19.82 \pm 0.80^{\mathrm{aA}}$ \\
\hline Yoghurt 5\% & $60.07 \pm 0.57 \mathrm{bC}$ & $55.01 \pm 0.68^{\mathrm{bC}}$ & $49.79 \pm 0.47 \mathrm{bc}$ & $39.47 \pm 0.28^{\mathrm{bB}}$ & $30.63 \pm 0.73^{\mathrm{bA}}$ \\
\hline Yoghurt 7.5\% & $69.15 \pm 0.24^{\mathrm{cC}}$ & $64.64 \pm 0.68^{\mathrm{cC}}$ & $60.07 \pm 0.57 \mathrm{cC}$ & $52.53 \pm 1.06^{\mathrm{cB}}$ & $44.61 \pm 0.56^{\mathrm{cA}}$ \\
\hline Yoghurt 10\% & $75.79 \pm 0.72^{\mathrm{dC}}$ & $70.85 \pm 0.51^{\mathrm{dC}}$ & $64.64 \pm 0.68 \mathrm{dC}$ & $57.26 \pm 1.01^{\mathrm{dB}}$ & $49.79 \pm 0.58^{\mathrm{dA}}$ \\
\hline
\end{tabular}

Ref: ${ }^{a-d}$ on the same column with different lowercase shows a significant difference in lakum fruit extract concentration level $(p<0,05)$; A-D on the same row with different capital letter shows significant difference with storage time $(\mathrm{p}<0,05)$

(t90) of lakum fruit extract and lakum fruit extract fortified yoghurt formula on reaction order one shows that t90 of yoghurt is around 5.24-7.95 days. Meanwhile, on lakum fruit extract shows a shorter t90 which is around 3.63-4.51 days. The degradation of quality during storage is influenced by reaction such as oxidation, flavor compound degradation, texture changes due to water contribution and color changes (Irsyad and friends. 2017). This shows that lakum fruit extract formulated on the form of yoghurt with low acidity can improve its anthocyanin content stability. It is in accordance to the research by Neliyanti and Idiawati (2014) which stated that anthocyanin in lakum fruit has a high stability if kept on low temperature, acidic condition, and without exposure to light.

A reaction can be determined as order reaction one if the reaction rate depends on the single reactant concentration. On this type, a single substance directly degrade into one product or more. The reaction is directly proportional with substance concentration that reacts. It is in accordance to research result by Hayati, and friends. (2012), that the total reduction degradation rate of anthocyanin on rosella flower petals toward heating temperature timing follows the first order of reaction. Besides, the same result is also found by Ulfiah (2014) that the changes of anthocyanin content on maltodextrin coated purple sweet potato on capsule form follows the 1 st order of reaction. Thus, based on storage stability in 28 days, lakum fruit extract fortified yoghurt with the best stability is $7.5 \%$ concentration, so it can be used as foodstuff for 7.95 days if kept on temperature $4^{\circ} \mathrm{C}$ or refrigerated.

\section{Stability of Anthocyanin Activity on Lakum Fruit Extract and Lakum Fruit Extract Fortified Yoghurt}

The stability result of antioxidant activity on lakum fruit extract and lakum fruit extract fortified yoghurt (Table III) 10\% lakum fruit extract yoghurt formula has the highest antioxidant activity (\% of inhibition), where the higher 
Table IV. Evaluation Result of Lakum Extract Fortified Yoghurt

\begin{tabular}{|c|c|c|c|c|c|}
\hline \multirow[b]{2}{*}{ Evaluation } & \multicolumn{4}{|c|}{ Result } & \multirow[b]{2}{*}{$\begin{array}{c}\text { Standard } \\
\text { Indonesia Nationa }\end{array}$} \\
\hline & $\begin{array}{c}\text { F I } \\
\text { Plain }\end{array}$ & $\begin{array}{c}\text { F II } \\
\text { Lakum 5\% }\end{array}$ & $\begin{array}{c}\text { F III } \\
\text { Lakum } 7.5 \%\end{array}$ & $\begin{array}{c}\text { F IV } \\
\text { Lakum } 10 \%\end{array}$ & \\
\hline Total BAL & $42,10^{7} \pm 2,0^{a}$ & $47,10^{7} \pm 1,0^{\mathrm{b}}$ & $48.2,10^{7} \pm 0.52^{b c}$ & $49.5,10^{7} \pm 0.55^{c}$ & Min. $10^{7}$ \\
\hline Fat Content & $4.13 \pm 0.09 c$ & $3.95 \pm 0.04 \mathrm{bc}$ & $3.73 \pm 0.03^{b}$ & $3.52 \pm 0.04^{\mathrm{a}}$ & Min. $3.0 \%$ \\
\hline $\mathrm{pH}$ & $4.25 \pm 0.13^{c}$ & $4.06 \pm 0.06^{b c}$ & $3.87 \pm 0.03^{b}$ & $3.62 \pm 0.03^{a}$ & Max. 4.5 \\
\hline Total Acid & $0.74 \pm 0.2^{\mathrm{a}}$ & $0.78 \pm 0.12^{\mathrm{b}}$ & $0.83 \pm 0.06^{b c}$ & $0.90 \pm 0.15^{c}$ & $0.5-2.0 \%$ \\
\hline Viscosity (cP) & $825.20 \pm 4.18^{c}$ & $762.78 \pm 3.87 \mathrm{bc}$ & $639.07 \pm 2.06^{b}$ & $510.88 \pm 3.15^{a}$ & - \\
\hline Protein Content & $2.80 \pm 0.12^{\mathrm{a}}$ & $3.26 \pm 0.4^{\mathrm{ab}}$ & $4.90 \pm 0.11^{\mathrm{b}}$ & $5.04 \pm 0.28^{c}$ & Min. $2.7 \%$ \\
\hline
\end{tabular}

Ref: ${ }^{\text {a-c }}$ on the same line with different lowercase shows a significant difference in lakum fruit extract concentration level $(\mathrm{p}<0,05)$

anthocyanin compound content on the extract, the higher the antioxidant activity. It is due to antioxidant substances on the lakum extract pigment, such as anthocyanin pigment (Widhiana, et al., 2012). Moreover, the average value of yoghurt antioxidant activities of lakum extract on day 0 is higher than lakum extract approximately between $60.07 \pm 0.57 \%-75.79 \pm 0.72 \%$, meanwhile the average $\%$ of inhibition of lakum extract is around $50.91 \pm 0.52 \%-64.64 \pm 0.68 \%$, due to plain yoghurt formula has antioxidant activity $(45.48 \pm 1.88 \%)$ obtained from components in yoghurt, so \% of inhibition in yoghurt is higher with antochyanin substances from lakum extract and components in yoghurt. This is in line with the research of Mohamed et al., (2014) stating that yoghurt as functional foodstuff due to the bioactive compound components such as peptide active and amino acid acting as antioxidants, thus the stability and product quality of lakum extract in yoghurt formula will increase.

\section{Evaluation Result of Lakum Extract Fortified Yoghurt}

Total BAL (Table IV) indicates that yoghurt produced on each treatments are ranged from $42.10^{7} \pm 2,0$ colony /gram $-49.5,10^{7} \pm 0.55$ colony/ gram. Produced yoghurt formula still meet the standard amount of BAL corpuscle, at least $10^{7}$ colony/gram (SNI, 2009). The addition of lakum extract may improve growth rate of BAL because lakum extract has carbohydrate substance used by BAL to produce lactic acid as primary product (Kumar et al., 2012). The combination of Lactobacillus bulgaricus with Streptococcus thermophillus give a better growth, since during incubation period yoghurt starter provides nutrients as stimulator for second growth of bacteria (Muhsinin et al., 2016).

The evaluation result of yoghurt (Table IV) indicates that the highest fat content is in plain yoghurt $(4.13 \pm 0.09 \%)$, the lowest fat content is in
$10 \%$ lakum extract-fortified yoghurt $(3.52 \pm 0.04 \%)$. Fat content obtained in this research is in accordance with SNI (2009) that is minimum $3.0 \%$. Fat content in yoghurt is determined by its base material, full-cream milk which contain high fat. According to the fat content value obtained, it can be observed that increased concentration of lakum extract is able to lower fat content of yoghurt because of water content of lakum extract is high, in accordance with research result of Mulyani et al., (2016) stating that the higher water content of extract, the lower the fat content of Soyghurt from plaintain rinds.

Evaluation result of yoghurt (Table IV) indicates that the lowest $\mathrm{pH}$ is in $10 \%$ lakum extract yoghurt $(3.62 \pm 0.03)$, while the highest $\mathrm{pH}$ is in plain yoghurt $(4.25 \pm 0.13 \%)$. The $\mathrm{pH}$ value of each yoghurt formulas obtained indicate normal $\mathrm{pH}$ range value for yoghurt product, as stated by Pereira, Barros, and Ferreira (2013) formation of lactic acid induces sour taste in yoghurt and maximum $\mathrm{pH}$ 4.5. The low $\mathrm{pH}$ value of yoghurt with the addition of lakum extract may be influenced by the acidity of lakum pigment extract and the symbiosis between lactic acid bacteria with antioxidant substances. Moreover, low $\mathrm{pH}$ in product has a role in suppressing the growth rate of other unwanted microorganisms (Widagdha and Nisa, 2015).

The evaluation result of yoghurt (Table IV) shows that the lowest acid amount in plain yoghurt $(0.74 \pm 0.2 \%)$, while the highest acid amount is in $10 \%$ lakum extract yoghurt $(0.90 \pm 0.15)$. Acid amount obtained in this research is in accordance with SNI (2009) that is between 0.5-2.0\%. Level enhancement of lakum extract addition linearly affect lactic acid enhancement rate associated with $\beta$-gal become more effective with active compounds such as flavonoid and anthocyanin derivatives that are high within lakum extract. It has a high lactic acid level, as the application of mixed starter Lactobacillus bulgaricus might 
release valine, glycine, and histidine amino acid required by Streptococcus thermophilus, otherwise Streptococcus thermophilus helps reduce $\mathrm{pH}$ and produce formic acid to stimulates Lactobacillus bulgaricus growth (Muhsinin et al., 2016).

The evaluation result of yoghurt (Table IV) shows that the highest viscosity is found in plain yoghurt (825.20 $\pm 4.18 \mathrm{cP})$ and the lowest viscosity is in $10 \%$ lakum extract yoghurt $(510.88 \pm 3.15 \mathrm{cP})$. Viscosity impairment in lakum extract fortified yoghurt may be influenced by the addition of lakum extract into yoghurt. The higher concentration of lakum extract added, the greater the amount of free water content available so that the viscosity decreases. This is in line with the research result by Febrihantana et al., (2015) stating that with the increased concentration of carrot juice with high water content, the viscosity of yoghurt produced decreases. Furthermore, the inoculation of lactic acid bacteria starter Lactobacillus bulgaricus and Streptococcus thermophillus in the amount of 5\% with $1: 1$ ratio may produce better yoghurt viscosity.

The evaluation result of yoghurt (Table IV) shows that the highest protein content is in $10 \%$ lakum extract yoghurt $(5.04 \pm 0.28 \%)$, and the lowest protein content is in plain yoghurt $(2.80 \pm 0.12 \%)$. Protein content obtained in this research is in accordance with SNI (2009) that is minimum $2.7 \%$. High protein content in yoghurt with the addition of lakum extract is due to the protein, carbohydrate, water, vitamin, and mineral contents in lakum fruits (Kumar et al., 2012). Mulyani et al., (2016) stating that the protein content of yoghurt is determined by the quantity of additional ingredients, the higher the protein content in additional ingredients, then the higher the protein content of yoghurt produced.

Based on organoleptic and sensory test, the plain yoghurt used as comparison is rather disliked by panelists with score of 3.74. Meanwhile the lakum extract fortified yoghurt is liked by panelists with score of (6.28-6.88). The best result of hedonic test for yoghurt produced with score of 6.88 (liked) and organoleptic purple (5), distinctive aroma of lakum (4.95), sour taste (4.85), fine texture (4.9), and rather liquid viscosity (4.85) is lakum extract yoghurt with $7.5 \%$ concentration. It is in line with the research by Panarigas and Idiawati (2015) applying purple lakum extract as natural coloring that has high anthocyanin pigment in cold beverages and agar jelly, where according to organoleptic test the addition of lakum extract is most preferred at a concentration of $7.5 \%$.

Anthocyanin has antioxidant benefits by acting as electron donor or hydrogen atom transfer on free radicals (Widhiana et al., 2012). The research of Neliyanti and Idiawati (2014) explained that anthocyanin in lakum extract has high stability if stored in low temperature, acidic state, and with no exposure to light. Where the influence of long duration of sunlight and light on lakum extract may cause the degradation of absorbance, since water when exposed directly to sunlight can stimulate the formation of hydrogen peroxide $\left(\mathrm{H}_{2} \mathrm{O}_{2}\right)$, that is able to decomposed colorproducing compound that may cause the color to fade, resulting in a decline of antioxidant activity. Moreover, the addition of $\mathrm{pH}$ may cause an increase in absorbance value which affects the color change in anthocyanin extract, so the lower the $\mathrm{pH}$ added, the brighter the color and the antioxidant activity will increase.

\section{CONCLUSION}

Lakum extract fortified yoghurt (Cayratia trifolia (L.) Domin has better anthocyanin stability and antioxidant activity, meeting the requirements of Indonesian National Standard (SNI/Standar Nasional Indonesia), and at concentration of 7.5\% provides the most likability from respondents.

\section{ACKNOWLEDGEMENTS}

Thanks to Akademi Farmasi Yarsi Pontianak for their support and funds during the research.

\section{REFERENCES}

Badan Standarisasi Nasional, 2009, SNI 01.12982009 Yoghurt, Badan Standarisasi Nasional, Jakarta.

Febrihantana, W., Radiati, L.,E., and Thohari, I. 2015. Pengaruh Penambahan Sari Wortel Sebagai Fortifikasi Produk Yogurt Ditinjau Dari Nilai pH, Total Asam Tertitrasi, Total Bakteri Asam Laktat, Viskositas Dan Total Karoten. Fakultas Peternakan Universitas Brawijaya, Malang.

Hayati, E. K. Budi, U.S. And Hermawan, R. 2012. Konsentrasi Total Senyawa Antosianin Ekstrak Kelopak Bunga Rosella (Hibiscus sabdariffa L.) :Pengaruh Temperatur dan PH. Jurnal Kimia, 6(12) : 138-147.

Irsyad, M., Mappiratu, and Rahim, A. 2017. Produksi Antosianin Tersalut Maltodekstrin dari Kelopak Bunga Rosella (Hibiscus Sabdariffa, L.) dan Aplikasinya dalam Pengolahan Pangan Fungsional, Jurnal Mitra Sains, 5(1): 12-25.

Kumar, D., Gupta, J., Kumar, S., Arya, R., Kumar, T. and Gupta, A., 2012, Pharmacognostic Evaluation of Cayratia trifolia (Linn.) Leaf, Asian Pacific Journal of Tropical Biomedicine, 
2(1):6-10.

Mohamed, A.G., A. F. Zayan and Nadia, M. Shahein, 2014, Physiochemical and sensory evaluation of yoghurt fortified with dietary fiber and phenolic compounds. Life Science Journal, 11(9):816-822

Muhsinin, S., Rizaldi, R., Gozali D., 2016. Formulasi Produk Minuman Probiotik (Yoghurt) dari Sari Jagung Manis (Zea Mays L.) dengan Penambahan Bakteri Probiotik Lactobacillus bulgaricus dan Streptococcus thermophilus, Jurnal Farmasi Galenika,3(1): 2406-9299

Mulyani, S., Fajariyah, N., and Pratiwi., W., 2016. Profil Kadar Protein, Kadar Lemak, Keasamaan, dan Organoleptik Soyghurt Kulit Buah Pisang Raja (Musa textillia) pada Variasi Suhu dan Waktu Fermentasi, Jurnal Kimia dan Pendidikan Kimia (JKPK), 1(2):4857.

Neliyanti and Idiawati, N., 2014, Ekstraksi dan Uji Stabilitas Zat Warna Alami dari Buah Lakum (Cayratia trifolia (L.) Domin), J. Kim. Khatulistiwa, 3(2): 86-93.

Panarigas, D, and Idiawati, N., 2015, Stabilitas Ekstrak Pigmen dari Buah Lakum (Cayratia trifolia (L.) Domin), dan Aplikasinya sebagai Pewarna Pangan, J. Kim. Khatulistiwa, 4(3):1-8.
Pereira, E.,L,Barros and Ferreira, 2013, Relevance of the Mention of Antioxidant Properties in Yogurt Labels: In Vitro Evaluation and Chromatographic Analysis, Antioxidants, 2:62-76.

Ulfiah, 2014. Kajian Masa Simpan Ekstrak Antosianin Ubi Jalar Ungu (Ipomea Batatas L. var Ayamurasaki) tercampur Maltodekstrin dalam Kemasan Kapsul, Jurusan Kimia Fakultas Matematika dan Ilmu Pengetahuan Alam Universitas Tadulako, Palu.

Widagdha, S., Nisa, F.C., 2015, Pengaruh Penambahan Sari Anggur (Vitis vinifera L.) dan Lama Fermentasi Terhadap Karakteristik Fisiko Kimia Yoghurt, Jurnal Pangan dan Agroindustri, 3(1):248-258.

Widhiana, E.T., Fitriana, N., Neliyanti and Anugrah, E.T., 2012, Skrining Fitokimia dan Aktivitas Antioksidan Buah Lakum (Vitis diffusa) dalam Berbagai Fraksi Khas Kalimantan Barat, Reseacrh Report, Fakultas MIPA Universitas Tanjungpura, Pontianak.

Yeo, C.K., Ang, W.F., Lok, A.F.S.L., dan Ong, K.H., 2012, Cayratya Juss. (Vitaceae) of Singapore: With A Special Note On Cayratia japonica (Thunb.) Gagnep, J.,Nature In Singapore, 5:331-338. 